\title{
Sediment-water oxygen and nutrient exchanges along a depth gradient in the Baltic Sea
}

\author{
K. Koop ${ }^{1}$, W. R. Boynton ${ }^{2}$, F. Wulff ${ }^{3}$, R. Carman ${ }^{4}$ \\ ${ }^{1}$ Zoology Department, University of Stockholm, S-106 91 Stockholm, Sweden \\ ${ }^{2}$ Chesapeake Biological Laboratory, Center for Environmental and Estuarine Studies, University of Maryland, PO Box 38 , \\ Solomons, Maryland 20688, USA \\ ${ }^{3}$ Askö Laboratory, Institute of Marine Ecology, University of Stockholm, S-106 91 Stockholm, Sweden \\ ${ }^{4}$ Department of Geology, University of Stockholm, S-106 91 Stockholm, Sweden
}

\begin{abstract}
Bottom water and sediment characteristics and net sediment-water fluxes of oxygen, nitrogen, phosphorus and hydrogen sulphide were measured under oxic and experimentally induced anoxic conditions along a depth gradient $(47$ to $130 \mathrm{~m}$ ) during summer in the Baltic proper. Temperature, salinity and dissolved nutrient concentrations (particularly phosphorus and nitrate) in bottom waters increased with depth while oxygen concentrations decreased sharply. Sediment organic content was much higher in sediments located beneath the permanent pycnocline (ca $65 \mathrm{~m}$ ). Sediments at all stations were somewhat depleted in total $N$ relative to total $C(C: N=10)$. Sediments at the shallow station $(47 \mathrm{~m})$ were highly enriched with total $P$ relative to $C$ or $N(C: N: P=18: 2: 1)$ but were somewhat depleted in $P$ at the deeper stations $(C: N: P \approx 120: 12: 1)$. Under oxic conditions oxygen fluxes ranged from 214 to $777 \mu \mathrm{mol} \mathrm{O} \mathrm{m} \mathrm{m}^{-2} \mathrm{~h}^{-1}$ and decreased with depth. Phosphorus and nitrite fluxes were always very small and were directed either into or out of the sediments. Ammonium fluxes were small (1 to 30 $\mu \mathrm{mol} \mathrm{N} \mathrm{m}^{-2} \mathrm{~h}^{-1}$ ) at all stations and did not exhibit a clear pattern with depth; $\mathrm{O}: \mathrm{N}-\mathrm{NH}_{4}$ flux ratios were close to expected 'Redfield ratios' at the deep station (16:1) but were much higher (>55:1) at the shallower sites indicating that processes other than only ammonification were taking place in sediments. Nitrate was always consumed by sediments (ca 1 to $16 \mu \mathrm{mol} \mathrm{N} \mathrm{m} \mathrm{N}^{-2} \mathrm{~h}^{-1}$ ) and fluxes were proportional to nitrate concentrations in the overlying water. Under anoxic conditions there was a dramatic increase in $\mathrm{P}-\mathrm{PO}_{4}$ fluxes $\left(2\right.$ to $\left.40 \mu \mathrm{mol} \mathrm{P} \mathrm{m}{ }^{-2} \mathrm{~h}^{-1}\right)$ and a smaller increase in $\mathrm{N}-\mathrm{NH}_{4}$ fluxes (14 to $\left.35 \mu \mathrm{mol} \mathrm{N} \mathrm{m}{ }^{-2} \mathrm{~h}^{-1}\right)$. Large hydrogen sulphide fluxes $\left(>40 \mu \mathrm{mol} \mathrm{S} \mathrm{m} \mathrm{m}^{-2} \mathrm{~h}^{-1}\right)$ were observed in sediments from the deepest station only. Under oxic conditions sediment recycling of $N$ and particularly of $P$ were small compared to estimated rates of burial of $\mathrm{P}$ and burial plus denitrification of $\mathrm{N}$. However, under anoxic conditions, sediment recycling of both $\mathrm{N}$ and $\mathrm{P}$ were similar to or much greater than sediment loss terms of burial and denitrification. Sediment regeneration under oxic conditions could supply 1 to $8 \%$ and 0 to $2 \%$ of estimated phytoplankton demand of $\mathrm{N}$ and $\mathrm{P}$, respectively; under anoxic conditions $12 \%$ of $\mathrm{N}$ and up to $200 \%$ of $\mathrm{P}$ demand could be met via sediment recycling
\end{abstract}

\section{INTRODUCTION}

In many shallow coastal and estuarine systems, sediment nutrient and oxygen dynamics have been found to exert an important influence on conditions in overlying waters and sediments (Zeitzschel 1980, Nixon \& Pilson 1983). Under various circumstances, sediments have been found to be an important temporary source of some compounds, a terminal sink for others and an interface in the ecosystem where a diversity of biogeochemical transformations occur (e.g. Blackburn \& Henriksen 1983). In many cases the magnitude of these sediment-water processes is sufficient to be a major component in oxygen or nutrient budget calcula- tions and hence also of importance in formulating estuarine management strategies. Concurrent with these observations, there has been an increased interest in understanding the regulation of these processes. Several environmental factors have emerged as often being significant, including the quantity and quality of organic matter reaching the sediment surface (Wassmann 1984, Jensen et al. 1988), infaunal community characteristics (Blackburn \& Henriksen 1983) and the chemical status of surficial sediments and overlying waters (Henriksen \& Kemp 1988). The interactive nature of such variables, however, often makes it difficult to identify cause-effect relationships.

We undertook a study of sediment-water nutrient 
exchanges in the central region of the Baltic Sea, for which there is a good record of traditional water quality measurements which suggest that the system has been undergoing cultural eutrophication for the past $100 \mathrm{yr}$ (Larsson et al. 1985). Nutrient budget calculations (Larsson et al. 1985, Rönner 1985) and recent numerical simulation model results (Stigebrandt \& Wulff 1987) suggest that sediments in this system play an important role in both nutrient and oxygen dynamics and hence have a particular relevance to the eutrophication issue. However, there are no direct measurements of sediment-water exchange from the Baltic proper from which to judge the accuracy of overall nutrient budget calculations and to calibrate and verify simulation modelling results. Some direct measurements exist from the shallow ( $<20 \mathrm{~m}$ ) Kiel Bight (Ruhmor et al. 1987) and the Bothnian Bay (Nedwell et al. 1983).
In this study we address the question of how sediment-water fluxes vary along a depth gradient in the Baltic proper and assess potential environmental controls on these fluxes. Specifically, we measured ambient sediment-water fluxes from 3 distinctive depth zones in the northern Baltic proper using intact sediment cores collected about 3 mo after the spring bloom period. In addition, we subjected these cores to experimentally induced anoxic conditions which occur periodically at each of these depth zones.

\section{SAMPLING LOCATIONS}

Three sampling locations were chosen in the northern Baltic proper, each representing different environmental conditions common in the Baltic (Table 1). The

Table 1. Bottom water and surface sediment ( 0 to $2 \mathrm{~mm}$ and 0 to $20 \mathrm{~mm}$ ) characteristics at the 3 sampling stations along the depth gradient in the Baltic Proper. Numbers in parentheses are from cores sampled at the end of the experiment

\begin{tabular}{|c|c|c|c|}
\hline Measure & 1 & $\begin{array}{c}\text { Station } \\
2\end{array}$ & 3 \\
\hline Latitude & $N 58^{\circ} 40^{\prime} 88^{\prime \prime}$ & $N 58^{\circ} 31^{\prime} 19^{\prime \prime}$ & N $58^{\circ} 29^{\prime} 73^{\prime \prime}$ \\
\hline Longitude & E $17^{\circ} 50^{\prime} 38^{\prime \prime}$ & E $18^{\circ} 02^{\prime} 60^{\prime \prime}$ & E $18^{\circ} 06^{\prime} 77^{\prime \prime}$ \\
\hline Depth $(m)$ & 47 & 82 & 130 \\
\hline \multicolumn{4}{|l|}{ Bottom water } \\
\hline Temp. $\left({ }^{\circ} \mathrm{C}\right)$ & 4.1 & 4.8 & 4.9 \\
\hline Salinity (units) & 6.9 & 8.2 & 9.4 \\
\hline Oxygen $\left(\mathrm{mg} \mathrm{l}^{-1}\right)$ & 13.7 & 6.3 & 1.8 \\
\hline Nitrate $\left(\mu \mathrm{mol} 1^{-1}\right)$ & 1.9 & 8.9 & 10.5 \\
\hline Nitrite $\left(\mu \mathrm{mol} \mathrm{l} \mathrm{l}^{-1}\right)$ & 0.2 & 0.3 & $<0.1$ \\
\hline Ammonia ( $\mu \mathrm{mol} \mathrm{I}^{-1}$ ) & 0.6 & 0.5 & 0.8 \\
\hline Phosphate $\left(\mu \mathrm{mol} \mathrm{l} \mathrm{l}^{-1}\right)$ & 0.9 & 2.7 & 3.7 \\
\hline $\mathrm{N}: \mathrm{P}$ (by atoms) & 3.0 & 3.6 & 3.1 \\
\hline \multicolumn{4}{|l|}{ Sediment $(0-2 \mathrm{~mm})$} \\
\hline Total carbon $(\%)$ & $3.6(1.4)$ & $10.2(7.8)$ & $7.1(7.5)$ \\
\hline Total nitrogen $(\%)$ & $0.35(0.16)$ & $1.31(0.93)$ & $0.83(0.88)$ \\
\hline$C: N$ (by atoms) & $12.0(10.2)$ & $9.1(9.8)$ & $10.0(10.0)$ \\
\hline \multicolumn{4}{|l|}{ Sediment $(0-20 \mathrm{~mm})$} \\
\hline Sediment $\mathrm{H}_{2} \mathrm{O}(\%)$ & 28.6 & 81.1 & 91.1 \\
\hline Bulk density $\left(\mathrm{g} \mathrm{cm}^{-3}\right)$ & 1.75 & 1.11 & 1.05 \\
\hline Total carbon $(\%)$ & $0.53(0.63)$ & $5.93(5.88)$ & $6.74(7.27)$ \\
\hline Total $C\left(\mathrm{~g} \mathrm{~m}^{-2}\right)$ & 133 & 249 & 126 \\
\hline Total nitrogen $(\%)$ & $0.076(0.076)$ & $0.73(0.72)$ & $0.79(0.84)$ \\
\hline Total $N\left(\mathrm{~g} \mathrm{~m}^{-2}\right)$ & 19 & 31 & 15 \\
\hline Total phosphorus (\%) & 0.076 & 0.150 & 0.130 \\
\hline Total P $\left(\mathrm{g} \mathrm{m}^{-2}\right)$ & 19 & 6 & 2 \\
\hline C:N:P (by atoms) & $18: 2: 1$ & $103: 11: 1$ & $134: 13: 1$ \\
\hline $\mathrm{C}: \mathrm{N}$ (by atoms) & $8.2(9.8)$ & $9.6(9.6)$ & $10.1(10.1)$ \\
\hline \multicolumn{4}{|l|}{ Sediment Eh $(\mathrm{mV})$} \\
\hline Overlying water & 425 & 420 & 370 \\
\hline Sediment surface & 434 & 430 & 380 \\
\hline $2 \mathrm{~mm}$ & 384 & 346 & 254 \\
\hline $10 \mathrm{~mm}$ & 271 & 232 & -18 \\
\hline $20 \mathrm{~mm}$ & 224 & 178 & -84 \\
\hline $200 \mathrm{mV}$ at depth $(\mathrm{mm})$ & 26 & 13 & 2.5 \\
\hline
\end{tabular}


first station was at $47 \mathrm{~m}$ water depth which is above the permanent halocline $(65 \mathrm{~m})$, rarely experiences severe hypoxia, has a well-established macrofaunal community and relatively low organic matter content (Ankar \& Elmgren 1976). The second station was in $82 \mathrm{~m}$ of water and may be subjected to seasonal hypoxia and anoxia. The infaunal community here is less well developed, sediments have a higher organic matter content and tend to have some degree of lamination. The third station was at $130 \mathrm{~m}$, a depth at which hypoxic and anoxic conditions commonly occur, and the macrofaunal community is poorly developed or absent for much of the year; sediment organic matter content is high and sediments are clearly laminated to depths of 4 to $5 \mathrm{~cm}$. Depths below $40 \mathrm{~m}$ represent about $70 \%$ of the total Baltic area but only $5 \%$ lies deeper than $150 \mathrm{~m}$ (Stigebrandt \& Wulff 1987). Temperatures at all stations were similar in early July $\left(4.5 \pm 0.4{ }^{\circ} \mathrm{C}\right)$. The stations were also outside the influence of the coastal archipelago zone so that primary production, nutrient conditions in euphotic waters and direct deposition of organic material to the sediments could be assumed to be similar among stations. Major differences among stations were largely related to differences in the sediment characteristics and those of the overlying waters.

\section{MATERIALS AND METHODS}

At each station 501 of near-bottom water was collected for later use in the laboratory measurements. Four intact sediment cores were obtained using a modified Kajak corer (Kajak et al. 1965, Blomqvist \& Abrahamsson 1985) equipped with an acrylic liner (8 $\mathrm{cm}$ diameter, $50 \mathrm{~cm}$ length, $2.5 \mathrm{~mm}$ wall thickness). In most cases the cores penetrated the sediment to a depth of about $20 \mathrm{~cm}$, the remaining core volume being filled with overlying water. Immediately after sampling, 4 of the cores were placed in a darkened, insulated chamber at ambient water temperature for transport to the laboratory. A vertical Eh-profile was taken on one core from each station using a platinum electrode slowly inserted into the sediment with a micromanipulator. A surficial sediment sample (top $2 \mathrm{~mm}$ ) was taken and triplicate samples analysed for particulate carbon (PC) and nitrogen (PN) content using an elemental analyser (Perkin-Elmer Model 240 B). Particulate phosphorous (PP) content was measured using persulphate oxidation followed by standard phosphate procedures (Parsons et al. 1984). The top $2 \mathrm{~cm}$ of sediments were also analysed for percent water, PC, $\mathrm{PN}$ and PP. These measurements were repeated on all cores at the end of the measurement period. Results from these analyses varied by less than $10 \%$ in all cases.
Three cores from each station were brought to the laboratory and maintained in the dark at $5 \pm 1{ }^{\circ} \mathrm{C}$ for the duration of the experimental period ( $33 \mathrm{~d}$ ). Larger animals, mainly amphipods, were removed and each core was fitted with water-tight plastic bottom and top stoppers, the latter with ports for sampling and addition of new water. A gentle circulation was maintained using magnetic stirring bars suspended within the cores. Water samples were withdrawn from the cores every $72 \mathrm{~h}$ and analysed for dissolved oxygen, phosphate, ammonium, nitrite, nitrate, and hydrogen sulphide following standard analytical methods (Parsons et al. 1984). Following each sampling, water was added to each core from reservoirs containing near-bottom water from the appropriate station. Net sediment-water fluxes were then calculated based on concentration differences between successive measurements, corrected for concentration changes due to the replacement water added after each sampling period and the surface-volume characteristics of each core. Concentration changes associated with the overlying water measured in control cores without sediments were always small

During the first 3 flux measurements ( 9 d) the sediment surface and overlying water in each core was maintained in an oxidised condition by the addition of oxygen-saturated water following each measurement period. Prior to making the fourth flux measurement about $75 \%$ of the overlying water was removed and replaced with water from the appropriate reservoir which had been bubbled with $\mathrm{N}_{2}$ gas to remove dissolved oxygen. After 3 d sampling was again resumed under anoxic conditions. All water added to the cores until Day 27 was stripped of oxygen prior to being used. We refer to this second phase of the experiment as the 'anoxic' phase although, after addition of new water, there were always small amounts of oxygen and nitrate present in the overlying water. This was always metabolised during the following incubation and the sediments themselves were anoxic, as evidenced by the production of hydrogen sulphide.

\section{RESULTS AND DISCUSSION}

\section{Characteristics of bottom waters and sediments along the depth gradient}

Measurements of bottom water and sediment characteristics from the 3 sampling stations are shown in Table 1 . Bottom water temperature and salinity ranged from 4.1 to $4.9^{\circ} \mathrm{C}$ and 6.9 to 9.4 units respectively, increasing slightly from the shallow to the deep station in both cases. Dissolved oxygen concentrations decreased sharply with depth from $13.7 \mathrm{mg} \mathrm{l}^{-1}$ at Stn 1 
to $1.8 \mathrm{mg} \mathrm{l}^{-1}$ at Stn 3 . Nitrate was the dominant form of dissolved inorganic nitrogen at all stations, ranging from $1.9 \mu \mathrm{mol} \mathrm{N} l^{-1}$ at Stn 1 to $10.5 \mu \mathrm{mol} \mathrm{N} l^{-1}$ at Stn 3 . Dissolved inorganic phosphorus concentrations also increased sharply along the depth gradient $(0.9$ to 3.7 umol $\left.\mathrm{P}^{-1}\right)$. The $\mathrm{N}$ : $\mathrm{P}$ ratio of dissolved inorganic $\mathrm{N}$ and $\mathrm{P}$ compounds $\left(\left(\mathrm{N}-\mathrm{NH}_{4}+\mathrm{N}-\mathrm{NO}_{3}+\mathrm{N}-\mathrm{NO}_{2}\right) / \mathrm{P}-\mathrm{PO}_{4}\right)$ in bottom waters was well below that expected based on simple oxidation of organic matter (16:1), indicating a preferential loss of $\mathrm{N}$ relative to $\mathrm{P}$.

Redox conditions in surface sediments (Table 1) at Stn 1 were relatively oxidised (redox $>200 \mathrm{mV}$ ) down to about $25 \mathrm{~mm}$ depth, whereas sediments from beneath the halocline (Stns 2 and 3 ) had shallower redoxclines, at 13 and $3 \mathrm{~mm}$, respectively. This is reflected in the physical appearances of the cores: the shallow cores had uniform light brown sediments with little evidence of black sulphide layers or zones. Cores from Stn 2 were light brown to gray in color with small zones of black sediment. The deep cores had distinct striations with layers 0.5 to $1.0 \mathrm{~mm}$ thick alternating between light gray and black down to at least $4 \mathrm{~cm}$ (Fig. 1). The surface of these cores had a growth of white filamentous bacteria, probably sulphide-oxidising Beggiatoa

There was a distinct gradient in total carbon content of the top $2 \mathrm{~cm}$ of the sediments with a range of 0.5 to $6.7 \%$ from the shallowest to the deepest station. Nitrogen content was similar at Stns 2 and 3 but an order of magnitude lower at Stn 1 (Table 1). C:N ratios showed an increase with depth, probably reflecting a change in the nature of the organic matter, with more refractory material in the deeper surface sediments.

Sediment characteristics data from the cores analysed after termination of the experiment showed little deviation from those at the beginning for most of the measurements. One notable exception was the change in both carbon and nitrogen content in the top $2 \mathrm{~mm}$ at the shallow station. Here total carbon content dropped by some $60 \%$ and total nitrogen by $55 \%$ during the 1 mo study resulting in a drop of the $C: N$ ratio from 12.0 to 10.2. There is no evidence, however, that cores from the shallow station were substrate-limited towards the end of the experiment because fluxes remained about equal during the whole study period (Table 2).

Fluxes of oxygen, nitrogen, phosphorus and sulphur along the depth gradient

Nutrient fluxes (mean $\pm \mathrm{SD}$ of 3 replicate cores) recorded during the $27 \mathrm{~d}$ experiment are shown in Table 2 , where positive values represent a loss from the sediment (i.e. a flux into the water) and negative values a flux from the overlying water into the sediment.



Station 1

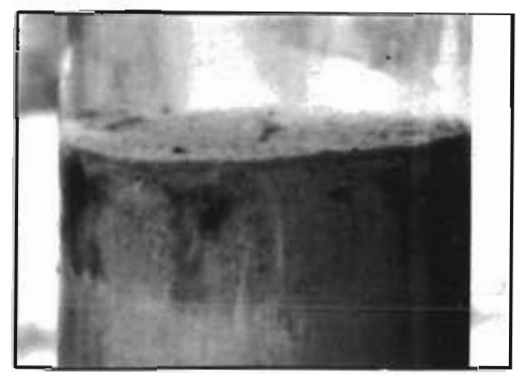

Station 2

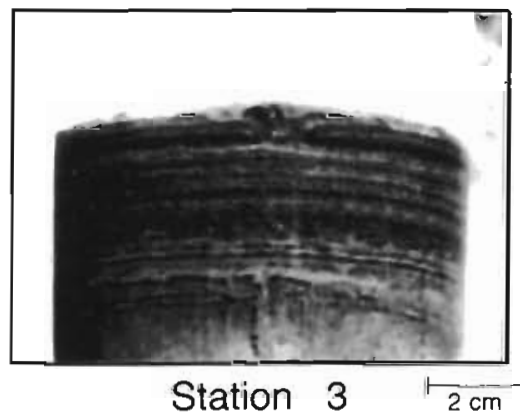

Fig. 1. Appearance of cores from 3 depths in the northern Baltic proper Stn $1,47 \mathrm{~m}$ : sediments appeared to be well mixed and light brown to well below $20 \mathrm{~mm}$. Stn $2,82 \mathrm{~m}$ : sediments were gray with some black zones apparent. Stn 3 . $130 \mathrm{~m}$ : sediments were obviously undisturbed by bioturbating organisms, laminations alternating between gray and black were obvious down to 40 or $50 \mathrm{~mm}$

Oxygen fluxes were always from the water into sediments but are reported as positive values to follow general conventions. The first 3 values (Days 3 through 9) were calculated during the oxic phase, the following 5 during the anoxic phase of the experiment (Days 15 through 27).

\section{Oxygen fluxes}

There were clear patterns of sediment oxygen consumption (SOC) along the depth gradient during the oxic phase of the experiment. Stn 1 consistently had the highest oxygen consumption rates; fluxes at Stn 2 were generally between 76 and $84 \%$ of those recorded from the shallowest station whereas those from the deep 





station were much lower, only 30 to $66 \%$ of those from Stn 1. During the anoxic phase, any oxygen added to the cores after sampling was always consumed during the $3 \mathrm{~d}$ incubation.

SOC values, although low when compared to measurements from other parts of the world, and particularly from highly productive ecosystems (Seiki et al. 1989), are within the range of measurements recorded from other parts of the Baltic Sea and the west coast of Sweden and Norway which characteristically lie between 500 and $1000 \mu \mathrm{mol} \mathrm{O} \mathrm{m}^{-2} \mathrm{~h}^{-1}$ (Table 3). Low SOC rates are directly related to the low temperatures which prevail in the Baltic Sea for most of the year, particularly in the deeper water, and to the supply of organic matter to sediments which is also low in our area. Primary production is about $150 \mathrm{~g} \mathrm{C} \mathrm{m}^{-2} \mathrm{yr}^{-1}$ (Elmgren 1984) of which 25 to $30 \%$ reaches the bottom, by which time it has also been partially degraded in the water (Table 1). Our estimates of SOC fit the empirical relationship between primary production plus organic input and benthic carbon mineralisation developed by Nixon \& Pilson (1983). Their relation indicates that a total annual organic input equal to $150 \mathrm{~g} \mathrm{C} \mathrm{M}^{-2} \mathrm{yr}^{-1}$ yields a benthic carbon mineralisation rate of $1070 \mu \mathrm{mol} O \mathrm{~m}^{-2} \mathrm{~h}^{-1}$, close to our measured values.

\section{Sulphide fluxes}

Environmentally significant sulphide fluxes were found only at Stn 3 during the anoxic phase of the experiment and these were quite variable (Table 2). Fluxes at Stn 3 were of the same order of magnitude as those recorded by Tuttle in portions of Chesapeake Bay (pers. comm.). Production of sulphide during anoxic conditions is respiration based on the use of $\mathrm{S}_{-} \mathrm{SO}_{4}$ as a terminal electron acceptor, and we can calculate an oxygen-based respiration rate equivalent to this production of sulphide assuming that sulphate is directly reduced to sulphide and that no other geochemical processes are involved (e.g. production of solid phase $S$ compounds). Our measured sulphide fluxes are equivalent to an SOC of between 14 and $2590 \mu \mathrm{mol} \mathrm{O} \mathrm{m} \mathrm{m}^{-2}$ $\mathrm{h}^{-1}$, with a mean value of $659 \mu \mathrm{mol} \mathrm{m} \mathrm{m}^{-2} \mathrm{~h}^{-1}$ at the $130 \mathrm{~m}$ station. These values are about equivalent to or higher than the SOC rates we recorded under oxic conditions.

The sulphide fluxes we observed on Day 18 were uncharacteristically low at all stations; we attribute this to a possible error in the measurements. Also, the reading for the deep station on Day 24 was much higher than any other measurement. This may be due to the fact that bottom waters at Stn 3 are frequently subjected to anoxic conditions and there may have been a build-up of $\mathrm{H}_{2} \mathrm{~S}$ beneath the surficial sediments. What we measured on that day may have been a pulse of sulphide which had diffused to the surface from deeper layers. Thus, the high flux may not represent metabolic processes occurring at the time of measurement. If Day 18 and 24 data are omitted (Table 2) mean sulphide fluxes during the anoxic period at $\operatorname{Stn} 3$ amounted to $58 \mu \mathrm{mol} \mathrm{S} \mathrm{m}{ }^{-2} \mathrm{~h}^{-1}$ which is equivalent to a respiration rate of $230 \mu \mathrm{mol} O \mathrm{~m}^{-2} \mathrm{~h}^{-1}$, similar to the respiration rates measured under oxic conditions.

The 2 shallower stations had much lower fluxes of sulphide, equivalent to means of 14 and $23 \mu \mathrm{mol} \mathrm{O} \mathrm{m}^{-2}$ $\mathrm{h}^{-1}$ at Stns 1 and 2, respectively. Fluxes increased slowly during the experimental period. Several explanations are possible. First, there could have been oxygen leaks in all the cores from Stns 1 and 2. This would have resulted in erroneously low fluxes as we suspected happened on Day 18. However, this seems unlikely because cores from all stations were treated alike and coefficients of variation were similar among all stations. A more likely explanation for these low fluxes is that a large fraction of the $\mathrm{S}_{-} \mathrm{SO}_{4}$ reduced went to solid phase sulphide (e.g. FeS and $\mathrm{FeS}_{2}$ ) rather than $\mathrm{H}_{2} \mathrm{~S}$. Tuttle et al. (pers. comm.) recently found that about $70 \%$ of the $\mathrm{S}-\mathrm{SO}_{4}$ reduced became monosulphides and pyrite in bioturbated, iron-rich sediments in Chesapeake Bay (USA). If processes of similar magnitude occurred at the 2 shallow stations in our experiments then much higher sulphide fluxes, equivalent to between 32 and $53 \mu \mathrm{mol} \mathrm{O} \mathrm{m}^{-2} \mathrm{~h}^{-1}$ can be calculated for these sediments.

\section{Phosphate fluxes}

Phosphate fluxes showed distinct patterns along the depth gradient. Fluxes during the oxic phase of the experiment were consistently low at all stations (Table 2) and were either positive or negative. During the anoxic phase phosphate fluxes were always positive, between 10 and $40 \mu \mathrm{mol} \mathrm{P} \mathrm{m} \mathrm{P}^{-2} \mathrm{~h}^{-1}$ at Stns 1 and 2 , but much lower ( 2 to 7 umol $\mathrm{P} \mathrm{m}^{-2} \mathrm{~h}^{-1}$ ) at the deep station.

A plot of phosphate fluxes versus ambient oxygen concentration in the overlying water is shown in Fig. 2. Oxygen concentrations above $1 \mathrm{~g} \mathrm{O}_{2} \mathrm{~m}^{-3}$ led to smail and variable phosphate fluxes. Below this concentration fluxes were generally positive and much higher. In contrast to most other fluxes measured in this study, phosphate fluxes recorded from our 3 stations are in the same range as those reported from other productive ecosystems (Seiki et al. 1989). Whereas carbon, oxygen and nitrogen transformations are controlled largely by biological processes, those of phosphorus are driven mostly by redox-dependent chemical reactions (Krom \& Berner 1980, Klump \& Martens 1981). Thus, these fluxes are likely to be very similar over a wide range of habitats if redox conditions favour phosphorus release 


\begin{tabular}{|c|c|c|c|c|c|c|c|c|c|}
\hline 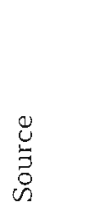 & 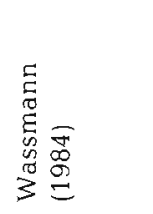 & 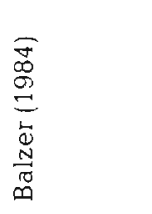 & 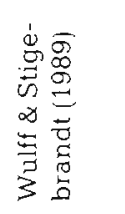 & 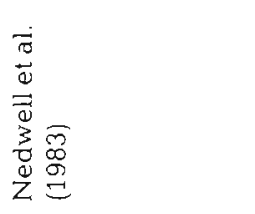 &  & 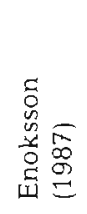 & 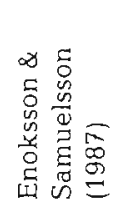 & 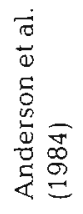 & 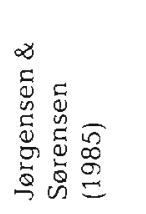 \\
\hline & 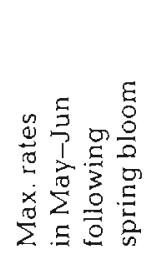 & 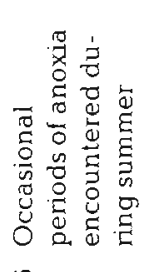 & 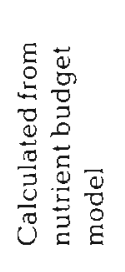 & 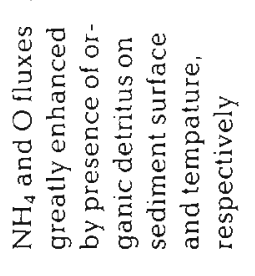 & 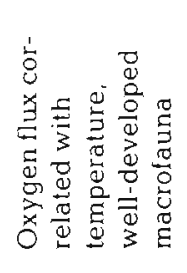 & 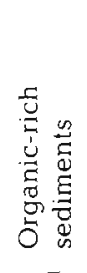 & & & 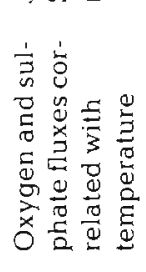 \\
\hline $\begin{array}{l}0 \\
0 \\
2 \\
2\end{array}$ & 1 & 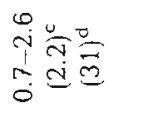 & 1 & 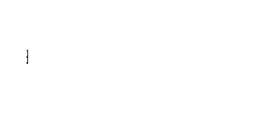 & 1 & $\begin{array}{l}\text { no } \\
10 \\
00 \\
01 \\
00\end{array}$ & 1 & 1 & I \\
\hline 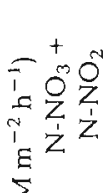 & । & $\begin{array}{l}\stackrel{0}{0} \\
\stackrel{0}{0} \\
\stackrel{0}{i}\end{array}$ & 1 & $\begin{array}{l}n \\
\infty \\
1 \\
\infty \\
i\end{array}$ & 1 & 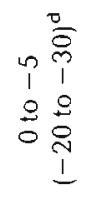 & 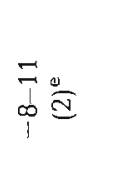 & $\underset{\infty}{m}$ & 1 \\
\hline  & 1 &  & 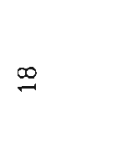 & 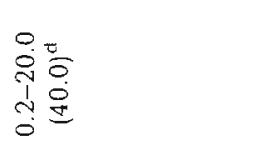 & 1 & 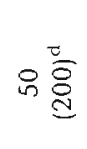 & 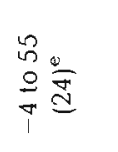 & $\Xi$ & 1 \\
\hline 0 & $\begin{array}{l}\tilde{O} \\
\stackrel{1}{1} \\
\stackrel{\sim}{\forall}\end{array}$ & 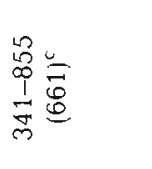 & I & 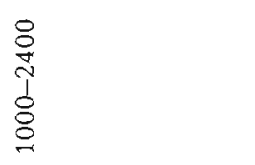 & $\stackrel{\frac{u}{0}}{\stackrel{8}{8}}$ & $\begin{array}{l}3 \\
0 \\
0 \\
7\end{array}$ & $\underset{0}{0}$ & $\stackrel{\infty}{\infty}$ & $\begin{array}{l}\tilde{B} \\
0 \\
0 \\
0 \\
0 \\
0\end{array}$ \\
\hline$\stackrel{\dot{a}}{\underline{G}} 0$ & $\underline{1}$ & $\stackrel{\infty}{\stackrel{\infty}{d}}$ & is & $\frac{n}{d}$ & $\frac{\rho}{1}$ & $\sigma$ &  & $\vec{\imath}$ & $\stackrel{\stackrel{\check{M}}{\sim}}{\mathrm{d}}$ \\
\hline 言 & $\begin{array}{l}8 \\
1 \\
0 \\
8\end{array}$ &  & 8 &  & $\approx$ & $\stackrel{\sim}{\circ}$ & ి్ల & 0 & - \\
\hline & $\frac{m}{1}$ & $\mathrm{~s}$ & 1 & 1 & 1 & 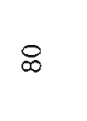 & 1 & $\infty$ & $\begin{array}{l}\vec{\infty} \\
\infty \\
\stackrel{\sigma}{0}\end{array}$ \\
\hline 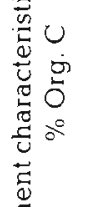 & $\stackrel{\mathscr{P}}{\stackrel{\sim}{\sim}}$ & 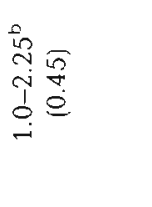 & 1 & 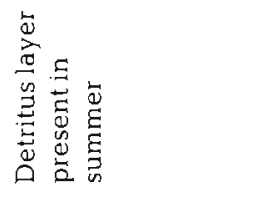 & 1 & $\ddot{m}$ & I & 1 & $\begin{array}{l}0 \\
0 \\
0 \\
0 \\
0\end{array}$ \\
\hline 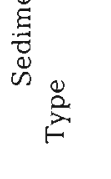 & 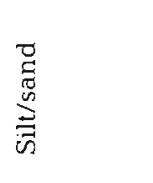 & 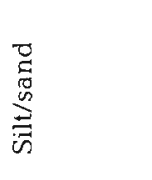 & 1 & $\begin{array}{l}\frac{ \pm}{\bar{n}} \\
\overline{0} \\
\bar{n}\end{array}$ &  & $\overrightarrow{\bar{n}}$ & 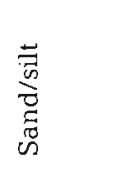 & 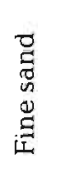 & $\overrightarrow{\bar{n}}$ \\
\hline 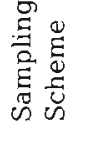 & 夏 & 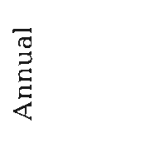 &  & $\underset{3}{\bar{a}}$ &  & $\stackrel{\text { ڤे }}{n}$ & $\begin{array}{l}0 \\
\stackrel{0}{0} \\
\text { ஸे }\end{array}$ & 1 & 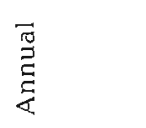 \\
\hline 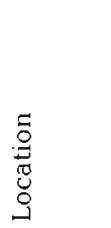 & 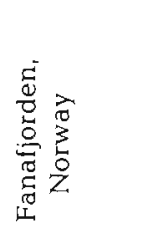 & 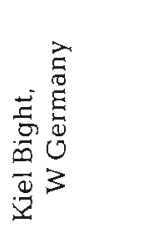 & 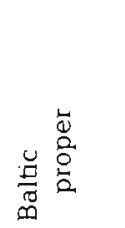 & 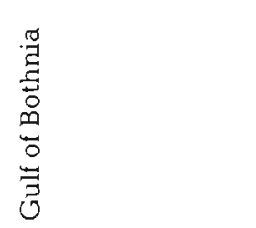 & 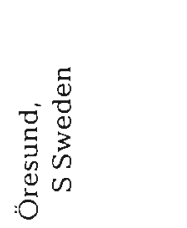 & 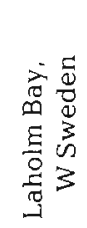 &  & 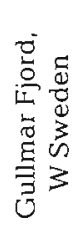 & 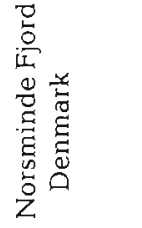 \\
\hline
\end{tabular}




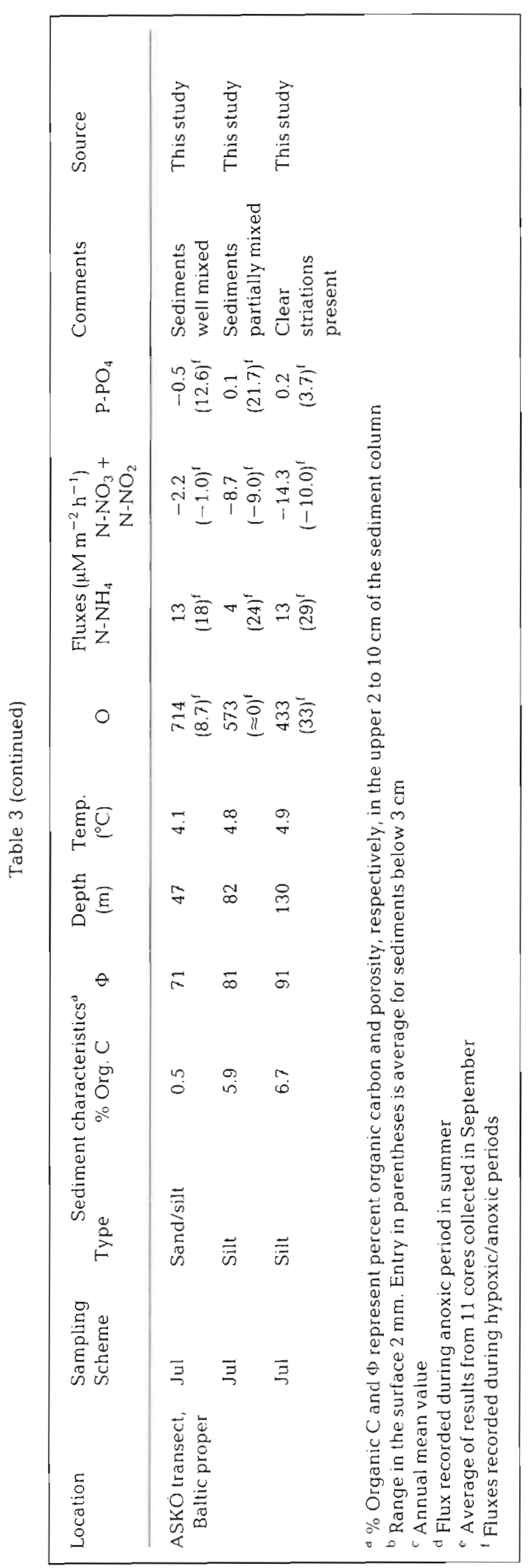

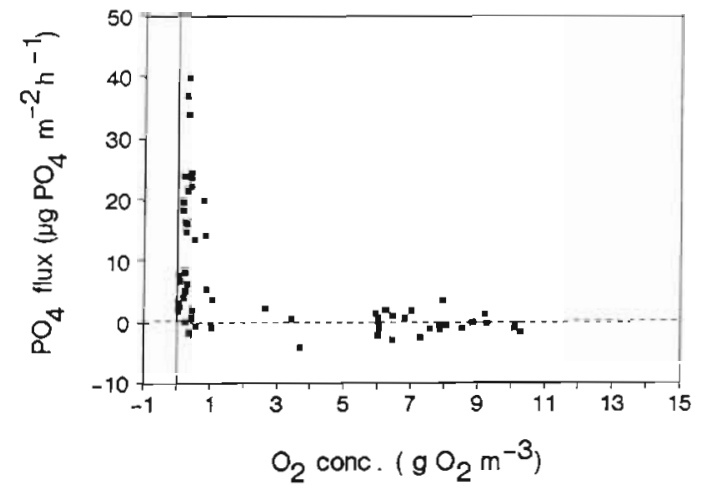

Fig. 2. Relationship between sediment phosphate fluxes and oxygen concentrations in the overlying water in the experiment using cores from 3 depths in the northern Baltic proper. Points from the oxic and anoxic phases of the experiment are pooled. Note that $\mathrm{P}_{-} \mathrm{PO}_{4}$ fluxes at $\mathrm{O}_{2}$ concentrations higher than $1 \mathrm{~g} \mathrm{O}_{2} \mathrm{~m}^{-3}$ are small and both positive and negative

and there is a usable pool of phosphorus available. The substantially lower phosphorus fluxes we observed at the deep station may reflect a depleted pool of available phosphorus because of the chronic exposure of these sediments to hypoxic or anoxic conditions.

\section{Ammonium fluxes}

Ammonium fluxes ranged from 1 to $35 \mu \mathrm{mol} \mathrm{N} \mathrm{m}^{-2}$ $\mathrm{h}^{-1}$ and agree with values recorded from elsewhere in the Baltic and the west coast of Sweden and Norway (Table 3). They are, however, at the low end of the range reported from other ecosystems (Seiki et al. 1989). Mean fluxes at Stns 1 and 3 were similar during the oxic phase (ca $15 \mu \mathrm{mol} \mathrm{N} \mathrm{m}{ }^{-2} \mathrm{~h}^{-1}$ ) whereas Stn 2 had values about 6 to 7 times lower. During the anoxic phase fluxes increased by factors of 15 and 2 at Stns 2 and 3 respectively, while fluxes at Stn 1 were of equal magnitude throughout the $27 \mathrm{~d}$ measurement period.

\section{Nitrite and nitrate}

Nitrite fluxes were always extremely small and were directed both into and out of sediment (Table 2).

Nitrate fluxes ranged between 0.5 and $24 \mu \mathrm{mol} \mathrm{N} \mathrm{m}^{-2}$ $\mathrm{h}^{-1}$ and were directed into sediments during the entire study period. During the anoxic phase any nitrate added after sampling was used up entirely during the following $3 \mathrm{~d}$ incubation period and hence fluxes measured during this period probably underestimate actual rates. Measured fluxes were within the range of values reported in other studies from northern Europe (see Table 3) although, as with oxygen and ammonium, they are low compared to results obtained in other. 
more productive, habitats. Nitrate entering sediments from the overlying water can be processed along 2 different pathways. First, it can be reduced to ammonium and enter the dissolved ammonium pool in the interstitial water and ultimately cross the sedimentwater interface to overlying waters. Alternatively, it can enter the denitrification pathway and be reduced to gaseous $\mathrm{N}_{2}$ which then leaves the system. As we have described above, ammonium fluxes in our study were generally lower than we would predict from direct biodegradation of organic matter to $\mathrm{N}-\mathrm{NH}_{4}$. Because $\mathrm{N}-\mathrm{NH}_{4}$ fluxes were low it seems likely that a proportion of the nitrate entering sediments was denitrified.

During the measurement period nitrate fluxes were directly proportional to nitrate concentrations in overlying waters. When all nitrate fluxes were plotted against the $\mathrm{N}-\mathrm{NO}_{3}$ concentration at the start of each $3 \mathrm{~d}$ incubation period a linear relationship of the form $y=$ $-1.78 x-0.18\left(r^{2}=0.66 ; n=62\right)$ was obtained (Fig. 3).

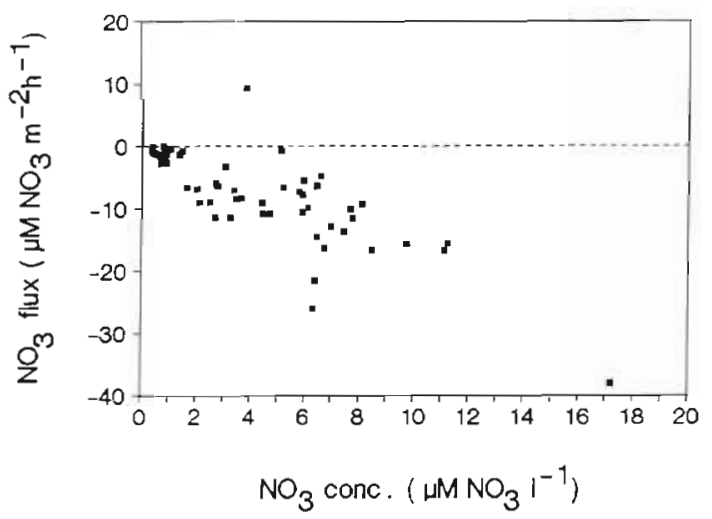

Fig. 3. Relationship between nitrate fluxes and nitrate concentrations in the overlying water in sediment cores from 3 depths in the northern Baltic proper. Points from both the oxic and anoxic phase of the experiment are plotted $y=-1.78 x-0.18$ $\left(\mathrm{r}^{2}=0.66, \mathrm{n}=62\right)$

\section{Nutrient flux ratios}

During aerobic decomposition of organic matter derived from phytoplankton, approximately 13.25 oxygen atoms are consumed for every atom of nitrogen released as ammonium (Redfield 1934). It is useful to examine our measured sediment-water fluxes for departures from such stoichiometric relationships and to relate these to other possible transformations in sediments. Mean $\mathrm{O}: \mathrm{N}$ flux ratios during the oxic phase of our experiment (using oxygen consumption and $\mathrm{N}-\mathrm{NH}_{4}$ fluxes) were 57,529 and 13 for Stns 1, 2 and 3, respectively. Only at $\operatorname{Stn} 3$ do calculated ratios agree with the expected Redfield ratio, indicating that organic material is being decomposed directly to
$\mathrm{N}-\mathrm{NH}_{4}$. At Stn 1, and particularly at Stn 2, ammonium fluxes are much lower than expected, indicating that other pathways must be active. One clear possibility is that the ammonium produced in the sediments is oxidised to nitrate and then denitrified. Also, nitrate fluxes were always directed into the sediments and this nitrate may have also been denitrified. This pattern of anomalously high $\mathrm{O}: \mathrm{N}$ ratios has been observed in other areas (e.g. Chesapeake Bay) under similar conditions (Boynton \& Kemp 1985). The expected mean ammonium production based on our measured oxygen consumption values is about $50 \mu \mathrm{mol} \mathrm{N} \mathrm{m}^{-2} \mathrm{~h}^{-1}$ for Stns 1 and 2 combined. This contrasts with an actual measured mean flux of about $7 \mu \mathrm{mol} \mathrm{N} \mathrm{m}^{-2} \mathrm{~h}^{-1}$, leaving $43 \mu \mathrm{mol} \mathrm{N} \mathrm{m}^{-2} \mathrm{~h}^{-1}$ unaccounted for. If we assume that this is denitrified and that the nitrate entering sediments from the water column (ca $6 \mu \mathrm{mol} \mathrm{N} \mathrm{m}^{-2} \mathrm{~h}^{-1}$ ) is also denitrified we calculate a total denitrification rate of about $49 \mu \mathrm{mol} \mathrm{N} \mathrm{m} \mathrm{m}^{-2} \mathrm{~h}^{-1}$. This is in agreement with other calculated and measured denitrification rates from similar areas (Table 4).

Flux ratios of $\mathrm{N}: \mathrm{P}\left(\mathrm{N}-\mathrm{NH}_{4}: \mathrm{P}-\mathrm{PO}_{4}\right)$ observed during the anoxic period of our experiment also depart markedly from expected Redfield ratios $(1.3,1.1$ and 9.0 for Stns 1 to 3, respectively). These very low ratios resulted from extremely high $\mathrm{P}_{-} \mathrm{PO}_{4}$ fluxes observed under anoxic conditions which exhibited a relatively larger increase than fluxes of $\mathrm{N}-\mathrm{NH}_{4}$ under similar conditions. Since the organic source for these sediments is mainly phytoplankton detritus with an initial N:P composition ratio of about 12:1 (Leppänen 1988) it is probable that the extreme departures from stoichiometric ratios that we observed at Stns 1 and 2 were of a transient nature resulting from the rapid release of recently deposited $P$ as well as $P$ sequestered in oxidised surficial sediments via mechanisms such as those suggested by Klump \& Martens (1981) and Carman \& Wulff (1989). Interestingly, sediments at the deepest station had N:P flux ratios closer to those expected based on the composition of the source material. Given the general anoxic conditions in overlying waters at this station, $P$ fluxes may be based solely on release from recently deposited material rather than a combination of both recently deposited and sequestered $\mathrm{P}$ compounds. It may be worth investigating how long very high $\mathrm{P}_{-} \mathrm{PO}_{4}$ fluxes relative to $\mathrm{N}$ fluxes can prevail because such information is useful in developing nutrient management strategies.

\section{Relationships between sediment characteristics and nutrient fluxes}

The C:N:P ratio of organic material is often used to characterise particulates, both with regard to organic 
Table 4. Environmental conditions and denitrification rates from the Baltic Sea and adjacent marine areas. -: no data available

\begin{tabular}{|c|c|c|c|c|c|c|c|c|}
\hline \multirow[t]{2}{*}{ Location } & \multirow{2}{*}{$\begin{array}{l}\text { Sampling } \\
\text { scheme }\end{array}$} & \multicolumn{3}{|c|}{ Sediment characteristics ${ }^{\alpha}$} & \multirow{2}{*}{$\begin{array}{l}\text { Depth } \\
\text { (m) }\end{array}$} & \multirow{2}{*}{$\begin{array}{l}\text { Temp } \\
\left({ }^{\circ} \mathrm{C}\right)\end{array}$} & \multirow{2}{*}{$\begin{array}{l}\text { Denitrification } \\
\left(u M \mathrm{Nm}^{-2} \mathrm{~h}^{-1}\right)\end{array}$} & \multirow[t]{2}{*}{ Source } \\
\hline & & Type & $\%$ Org. C & $\Phi$ & & & & \\
\hline $\begin{array}{l}\text { Laholm Bay, } \\
\text { W Sweden }\end{array}$ & Sept & Silt & 3.4 & 80 & 20 & 10 & $19-24$ & $\begin{array}{l}\text { Enoksson } \\
(1987)^{d}\end{array}$ \\
\hline $\begin{array}{l}\text { Aarhus Bight, } \\
\text { Denmark }\end{array}$ & Annual & Silt/clay & $2.6-11.4$ & $41-75$ & 15 & $4-13$ & $\begin{array}{l}4-21 \\
(42)^{b}\end{array}$ & $\begin{array}{l}\text { Jensen et al. } \\
(1988)^{e}\end{array}$ \\
\hline $\begin{array}{l}\text { Baltic Sea } \\
\text { proper }\end{array}$ & Annual & - & - & - & $0-450$ & 4 & 16 & $\begin{array}{l}\text { Wulff \& Stige- } \\
\text { brandt }(1989)^{\mathrm{i}}\end{array}$ \\
\hline $\begin{array}{l}\text { Lendrup Vig, } \\
\text { N Denmark }\end{array}$ & $\begin{array}{l}\text { Spring } \\
\text { Summer }\end{array}$ & Silt & 1.5 & - & $<1$ & $7-23$ & $13-213$ & $\begin{array}{l}\text { Andersen et al. } \\
(1984)^{e}\end{array}$ \\
\hline $\begin{array}{l}\text { Norsminde Fjord, } \\
\text { Denmark }\end{array}$ & Annual & $\begin{array}{l}\text { Silt } \\
\text { (mud flat) }\end{array}$ & $5-15$ & - & 0.5 & $0-20$ & $\begin{array}{c}83-416 \\
(205)^{c}\end{array}$ & $\begin{array}{l}\text { Jørgensen \& } \\
\text { Sørensen }(1988)^{e}\end{array}$ \\
\hline $\begin{array}{l}\text { Himmerfjärden, } \\
\text { SE Sweden }\end{array}$ & Annual & Silt & - & - & 30 & $1.5-10.0$ & $1.5-24.0$ & $\begin{array}{l}\text { Koop \& John- } \\
\text { stone (unpubl.) }\end{array}$ \\
\hline $\begin{array}{l}\text { Laholm Bay, } \\
\text { W Sweden }\end{array}$ & - & Silt & - & - & $17-20$ & 10 & 10 & $\begin{array}{l}\text { Sahlsten \& } \\
\text { Sörensson } \\
(1986)^{e}\end{array}$ \\
\hline $\begin{array}{l}\text { Baltic proper } \\
\text { deep water }\end{array}$ & Annual & - & - & - & $>60$ & 4 & 74 & $\begin{array}{l}\text { Shaffer \& Rönner } \\
(1984)^{g}\end{array}$ \\
\hline Baltic proper & Annual & - & - & - & 55 & 4 & 14 & Rönner $(1985)^{e}$ \\
\hline $\begin{array}{l}\text { a } \% \text { Org. C and } \Phi \\
\text { b Maximum obser } \\
{ }^{c} \text { Mean annual rat } \\
\text { d Estimated from a } \\
\text { e Acetylene inhibi } \\
\text { 'Estimated from } n\end{array}$ & $\begin{array}{l}\text { present perc } \\
\text { ed rate } \\
\text { monium flu } \\
\text { on technique } \\
\text { rient budge }\end{array}$ & torganic car & on and poro & ity, resp & tively, in & urface sed & iments & \\
\hline
\end{tabular}

matter quality and origin. Phytoplankton detritus characteristically has $C: N$ ratios of around 7 and the ratio gets higher as the material becomes more refractory, with organic matter of terrestrial origin having values of 30 or more. The $\mathrm{C}: \mathrm{N}$ ratios of surficial sediments along our transect were around 10 indicating that some of the nitrogen in the sedimenting phytoplankton material had been lost. Superimposed on this general pattern there was a depth gradient of C:N ratios with the shallowest station having a value of 8.2 (top $20 \mathrm{~mm}$ ) increasing to 9.6 at the intermediate station and to 10.1 in the deepest sediments. This indicates a successive depletion of organic matter in $\mathrm{N}$ relative to $\mathrm{C}$ along the depth gradient. One explanation for this pattern is that material deposited in shallow water is likely to be resuspended frequently and, in the process, transported to deeper areas where it accumulates. During transport much of the labile nitrogen is likely to be rapidly recycled (Garber 1984) leaving only the more refractory material to be deposited in deeper areas. Such an explanation is consistent with the fact that organic matter content of sediments increases substantially with depth. An alternative explanation, which does not require invoking transport, is that the potential for denitrification of deposited
$\mathrm{N}$ increases with depth. This hypothesis could be tested by measuring denitrification along the depth gradient.

Particulate C:N:P ratios of surface sediment (top $20 \mathrm{~mm}$ ) also exhibited a wide range along the depth gradient (Table 1). The measured value of 18:2:1 at the $47 \mathrm{~m}$ station indicates that this material was highly enriched in phosphorus relative to both $\mathrm{C}$ and $\mathrm{N}$. This is in sharp contrast to sediments at the deeper Stns 2 and 3 which were both poorer in phosphorus with ratios of $103: 11: 1$ and $134: 13: 1$, respectively, quite close to the Redfield ratio of 106:16:1. High phosphate fluxes after the redox shift at Stn 1 and, particularly, Stn 2 suggest that there is a large pool of mobilisable phosphate in these sediments which is released when redox conditions permit. At Stn 3 fluxes during the anoxic phase of the experiment were much lower than at the other stations. Sediments at this station experience periodic anoxia in the bottom water during which the labile phosphorus fraction may be released into the water as during the anoxic phase of our experiment. Under such conditions most of the labile phosphorus is likely to have been removed from those sediments even though the total phosphorus content may still be rather high. Thus the $\mathrm{P}$ in apatite-phosphorus, for example, is very stable and is unaffected by ambient changes in oxygen 
and $\mathrm{pH}$. This appears to be the situation in the sediment at $\operatorname{Stn} 3$ where fluxes during the anoxic phase of our experiment were only about $20 \%$ of those recorded from Stn 1 and an order of magnitude less than those from Stn 2.

\section{Influence of sediment processes on water column characteristics and nutrient budgets}

The potential influence of sediment processes on nutrient budgets and water column characteristics can be evaluated by comparing the relative magnitude of appropriate terms. Thus we can compare the magnitude of release rates of $\mathrm{N}$ and $\mathrm{P}$ from sediments with phytoplankton demand for these nutrients as well as with the amounts of $N$ and $P$ lost through burial in deep sediments and that of $\mathrm{N}$ lost through denitrification. We are aware of the pitfalls of doing such comparisons using results from only one experiment. Obviously additional data are required before a more complete picture can be obtained. The following comparisons may, however, be useful as a first approximation.

In the Baltic proper annual rates of phytoplankton production have been estimated to be about $150 \mathrm{~g} \mathrm{C}$ $\mathrm{m}^{-2} \mathrm{yr}^{-1}$ (Elmgren 1984, Leppänen \& Kononen 1988). Since we did not have direct measurements of $\mathrm{N}$ and $\mathrm{P}$ uptake (e.g. Caperon et al. 1979) we used a Redfield composition ratio of $106: 16: 1$ coupled with primary production rates to develop estimates of daily phytoplankton nutrient demand (Redfield 1934, Boynton \& Kemp 1985). This approach yields demand estimates of about 216 and $14 \mu \mathrm{mol} \mathrm{m} \mathrm{m}^{-2} \mathrm{~h}^{-1}$ for $\mathrm{N}$ and $\mathrm{P}$ respectively. Comparing these values to the net sediment release rates of $\mathrm{N}-\mathrm{NH}_{4}$ and $\mathrm{P}-\mathrm{PO}_{4}$ during the oxic period (Table 2) we find that sediments supplied a small frac- tion of the required $N(1$ to $8 \%)$ and essentially no phosphorus $(0$ to $2 \%$ ). If we consider the net flux of $\mathrm{N}-\mathrm{NH}_{4}$ plus $\mathrm{N}-\mathrm{NO}_{3}$ across the sediment-water interface, the amount of $N$ potentially available to phytoplankton is even further reduced (Table 2) because nitrate was consistently consumed by the sediments.

In sharp contrast to these findings it appears that sediment regeneration of $\mathrm{N}-\mathrm{NH}_{4}$ and $\mathrm{P}_{-} \mathrm{PO}_{4}$ during anoxic periods can supply significant proportions of the phytoplankton demand, particularly of $P$, at the 2 shallower stations. Specifically, ammonium fluxes could supply 9,13 and $13 \%$ of estimated $N$ demands at Stns 1 to 3 , respectively. During the same period phosphate fluxes could supply 119, 200, and $30 \%$ of P demand, respectively. The large $P$ fluxes observed at the 2 shallower stations during induced hypoxia are particularly significant in terms of current eutrophication trends in the Baltic. As shown by Carman \& Wulff (1989) these sediments have the highest capacity for adsorbing phosphorus and also the highest concentrations of phosphorus calculated per unit area. From our present study it appears that they have a large capacity for releasing $P$ under low oxygen conditions. Such conditions occur only occasionally at present (Larsson et al. 1985) but if they became more frequent, they would, all other factors being equal, have the effect of enriching bottom waters with $P$ and further reducing already low $\mathrm{N}: \mathrm{P}$ ratios of dissolved nutrients in deep waters (Table 1).

A second approach in evaluating the significance of our measured sediment release rates is to compare them with sediment related loss terms of burial and denitrification. We have assembled available estimates of burial and denitrification rates from the Baltic and adjacent areas (Tables 4 and 5). Burial rates of $N$ and $P$ ranged from 5 to $24 \mu \mathrm{mol} \mathrm{N} \mathrm{m}{ }^{-2} \mathrm{~h}^{-1}$ and 0.5 to $0.8 \mu \mathrm{mol}$

Table 5. Estimates of burial rates of $\mathrm{N}$ and $\mathrm{P}$ from the Baltic Sea and adjacent areas. --: data not available

\begin{tabular}{|c|c|c|c|c|}
\hline \multirow[t]{2}{*}{ Location } & \multirow[t]{2}{*}{$\begin{array}{l}\text { Depth } \\
\text { (m) }\end{array}$} & \multicolumn{2}{|c|}{$\begin{array}{l}\text { Estimated burial rate } \\
\qquad\left(\mu \mathrm{M} \mathrm{m}^{-2} \mathrm{~h}^{-1}\right)\end{array}$} & \multirow[t]{2}{*}{ Source } \\
\hline & & $\mathrm{N}$ & $\mathrm{P}$ & \\
\hline Kiel Bight & 20 & $\sim 5$ & $\sim 0.5$ & Balzer $(1984)^{d}$ \\
\hline Baltic proper & $>60$ & $\sim 10$ & - & Shaffer $(1987)^{b}$ \\
\hline Baltic proper & $0-450$ & 22 & 0.5 & $\begin{array}{l}\text { Wulff \& Stigebrandt }(1989)^{b} \text { (note these values } \\
\text { are estimates for burial }+ \text { denitrification) }\end{array}$ \\
\hline N Baltic proper & 150 & $\sim 24$ & - & Leppänen $(1988)^{a}$ \\
\hline Fanafjorden, W Norway & $60-90$ & 8 & 0.8 & Wassmann $(1984)^{a}$ \\
\hline ASKÖ transect & $\begin{array}{r}47 \\
82 \\
130\end{array}$ & $\begin{array}{r}4.7 \\
29.4 \\
15.1\end{array}$ & $\begin{array}{l}0.7 \\
0.9 \\
0.3\end{array}$ & $\begin{array}{l}\text { This study } \mathrm{y}^{\mathrm{a}} \text { (assuming vertical accretion rate of } \\
\left.10 \mathrm{~mm} \mathrm{~m}^{-2} \mathrm{yr}^{-1}\right)\end{array}$ \\
\hline
\end{tabular}


$\mathrm{P} \mathrm{m}^{-2} \mathrm{~h}^{-1}$, and were similar to those calculated from our study (Asko transect). These rates of burial were similar or slightly higher than net fluxes of $\mathrm{N}$ during the oxic period of our experiment and very similar during the anoxic period. There was an order of magnitude shift in the relative rates of burial and sediment release between oxic and anoxic periods with releases of $P$ dominating during the latter period. A very considerable range in denitrification rates has been reported (1.5 to $416 \mu \mathrm{mol} \mathrm{N} \mathrm{m}^{-2} \mathrm{~h}^{-1}$ ) as indicated in Table 4. However, if rates from very shallow, organically rich areas which also have an external supply of nitrate, are eliminated, the majority of values are in the range 2 to $24 \mu \mathrm{mol} \mathrm{N} \mathrm{m} \mathrm{N}^{-2} \mathrm{~h}^{-1}$, again similar to rates of $\mathrm{NH}_{4}^{+}$flux which we observed.

While there are some uncertainties associated with these types of comparisons, the relative uniformity of burial and denitrification rates leads us to believe that we are not making order of magnitude errors. The major conclusions we draw from these data is that sediment recycling of $\mathrm{N}$ and $\mathrm{P}$ is more than balanced by the loss terms of burial and denitrification, especially under oxic conditions. Should anoxic conditions become more prevalent in time and space, however, we would expect sediment recycling of nitrogen and phosphorus to assume increasing importance because of the loss of the denitrification pathway (which would result from lower levels of $\mathrm{NO}_{3}^{-}$and the release of $P$ previously bound in the sediments. Both of these changes would exacerbate eutrophication tendencies.

There are a number of measurements that need to be made before a more complete understanding of the role of sediment processes in the Baltic proper can be obtained. First, there are virtually no direct measurements of processes such as sediment recycling of nitrogen and phosphorus, burial or denitrification for zones of the Baltic deeper than 20 to $30 \mathrm{~m}$. This may be an especially serious shortfall because our data suggest strong gradients related to depth and the mean depth of the Baltic is about $55 \mathrm{~m}$. Secondly, there is the obvious need to obtain measurements of these processes over at least one annual cycle, particularly during and immediately after settling of the spring bloom when others have observed substantially increased rates of many sediment processes (e.g. Enoksson \& Rüdén-Berg 1983, Wassmann 1984, Jensen et al. 1988). Finally, in the vast majority of sediment-water flux studies, measurements of $\mathrm{N}$ fluxes have included $\mathrm{N}$ $\mathrm{NH}_{4}, \mathrm{~N}-\mathrm{NO}_{3}$ and $\mathrm{N}-\mathrm{NO}_{2}$ but not dissolved organic nitrogen (DON), partly because early attempts failed to find interpretable fluxes (e.g. Boynton et al. 1980). Enoksson (1987), however, has more recently measured significant DON fluxes in Laholm Bay, on the Swedish west coast. It seems that the old issue of sediment DON fluxes will have to be revisited if we are to evaluate adequately total $\mathrm{N}$ processes at the sediment-water interface.

Acknowledgements. We thank Anders Sjösten and the chemistry laboratory of the Asko Lab. for doing some of the analyses and Lisa Matteson for preparing the figures. We appreciate the technical assistance received from Berndt Abrahamsson. Sven Blomqvist lent us some of his equipment, for which we are grateful. Discussions with Jon Tuttle and Mike Kemp were particularly useful. Financial assistance was provided through grants to $K . K$. and $F$. W. from the Swedish Environmental Protection Board. We thank B. O. Jansson for making available the facilities at the Askö field station.

\section{LITERATURE CITED}

Andersen, T K., Jensen, M. H., Sörensen, J. (1984). Diurnal variation of nitrogen cycling in coastal, marine sediments. Mar. Biol. 83: 171-176

Ankar, S., Elmgren, R. (1976). Benthic macro- and meiofauna of the Askö-Landsort area (northern Baltic proper). Contr. Askö Lab. 11, Univ. of Stockholm, $115 \mathrm{pp}$.

Balzer, W (1984). Organic matter degradation and biogenic element cycling in a nearshore sediment (Kiel Bight). Limnol. Oceanogr. 29: 1231-1246

Blackburn, H., Henriksen, K. (1983). Nitrogen cycling in different types of sediments from Danish waters. Limnol. Oceanogr 28: 477-493

Blomquist, S., Abrahamsson, B. (1985). An improved Kajaktype gravity core sampler for soft bottom sediments. Schweiz. Z. Hydrol. 47-81-84

Boynton, W. R., Kemp, W M. (1985). Nutrient regeneration and oxygen consumption by sediments along an estuarine salinity gradient. Mar. Ecol. Prog. Ser. 23: 45-55

Boynton, W. R., Kemp, W. M., Osborne, C. G. (1980). Nutrient fluxes across the sediment-water interface in the turbid zone of a coastal plain estuary. In: Kennedy, V S. (ed.) Estuarine perspectives. Academic Press, New York, p. 93-109

Caperon, J., Schell, D., Hirota, J., Laws, E. (1979). Ammonium excretion rates in Kaneohe Bay, Hawaii, measured by a ${ }^{15} \mathrm{~N}$ isotope dilution technique. Mar Biol. 54: 33-40

Carman, R., Wulff, F. (1989). Adsorption capacity of phosphorus in Baltic Sea sediments. Estuar. coast. Shelf Sci. 29: $447-456$

Elmgren, R. (1984). Trophic dynamics in the enclosed, brackish Baltic Sea Rapp. P.-v. Réun. Cons. int Explor. Mer 183: $152-169$

Enoksson, V (1987). Nutrient recycling by coastal sediments I1. Effects of temporary oxygen depletion. In: Ph. D. thesis Dept Marine Microbiology, Univ. Göteborg, Sweden. Part V.p. $1-19$

Enoksson, V., Rüdén-Berg (1983). A system for determining exchanges between sediment and water exemplified by nitrogen flux under controlled oxygen conditions. In: Hallberg, R. (ed.) Environmental biogeochemistry. Ecol. Bull 35. Publishing House/FRN, Stockholm, p. 243-250

Enoksson, V., Samuelsson, M.-O. (1987). Nitrification and dissimilatory ammonium production and their effects on nitrogen flux over the sediment-water interface in bioturbated coastal sediments. Mar. Ecol. Prog. Ser. 36: 181-189

Garber. J. H. (1984). Laboratory study of nitrogen and phosphorus remineralization during the decomposition of coastal plankton and seston. Estuar coast. Shelt. Sci. 18 $685-702$ 
Henriksen, K., Kemp, W. M. (1988). Nitrification in estuarine and coastal marine sediments. In: Blackburn, T H., Sorensen, J. (eds.) Nitrogen cycling in coastal marine environments. John Wiley, Chichester, p. 207-249

Jensen, M. H., Andersen, T K., Sorensen, J. (1988). Denitrification in coastal bay sediment: regional and seasonal variation in Aarhus Bight, Denmark. Mar Ecol. Prog. Ser. 48: 155-162

Jørgensen, B. B., Sorensen, J. (1985). Seasonal cycles of $\mathrm{O}_{2}$, $\mathrm{NO}_{3}{ }^{-}$and $\mathrm{SO}_{4}{ }^{2-}$ reduction in estuarine sediments: the significance of an $\mathrm{NO}_{3}{ }^{-}$reduction maximum in spring. Mar. Ecol. Prog. Ser. 24: 65-74

Jørgensen, K. S., Sørensen, J. (1988). Two annual maxima of nitrate reduction and denitrification in estuarine sediment (Norsminde Fjord, Denmark). Mar. Ecol. Prog. Ser. 48: $147-154$

Kajak, Z., Kacprzak, K., Polkowski, R. (1965), Tubular bottom sampler. Ekol. Pol. B 11: 159-165

Kanneworff, E., Christensen, H. (1986). Benthic community respiration in relation to sedimentation of phytoplankton in the Öresund. Ophelia 26: 269-284

Klump, J. V., Martens, C. S. (1981). Biogeochemical cycling in an organic rich coastal marine basin. II. Nutrient sedimentwater exchange processes. Geochim. Cosmochim. Acta 45: $101-121$

Krom, M. D., Berner, R. A. (1980). The diffusion coefficients of sulfate, ammonium and phosphate ions in anoxic marine sediments. Limnol. Oceanogr. 25: 327-337

Larsson, U., Elmgren, R., Wulff, F. (1985). Eutrophication and the Baltic Sea: causes and consequences. Ambio 14:9-14

Leppänen, J.-M. (1988). Cycling of organic matter during the vernal growth period in the open northern Baltic Proper VI. Sinking of particulate matter Finnish mar. Res. 255: $97-118$

Leppänen, J.-M., Kononen, K. (1988). Cycling of organic matter during the vernal growth period in the open northern Baltic Proper. III. Phytoplankton composition and estimation of loss rates of phytoplankton production. Finnish mar. Res. 255: 37-54

Nedwell, D. B., Hall, S.-E., Andersson, A., Hagström, A. F., Lindström, E. B. (1983). Seasonal changes in the distribution and exchange of inorganic nitrogen between sediment and water in the northern Baltic (Gulf of Bothnia). Estuar. coast. Shelf Sci. 17: 169-179

This article was submitted to the editor
Nixon, S. W., Pilson, M. E. Q. (1983). Nitrogen in estuarine and coastal marine ecosystems. In: Carpenter, E. J., Capone, D. G. (eds.) Nitrogen in the marine environment. Academic Press, New York, p. 565-648

Parsons, T. R., Maita, Y., Lalli, C. M. (1984). A manual of chemical and biological methods for seawater analysis. Pergamon Press, Sydney

Redfield, A. C. (1934). On the proportions of organic derivatives in seawater and their relation to the composition of plankton. In: James Johnstone Memorial Volume, Univ. Press, Liverpool, p. 176-192

Rönner, U. (1985). Nitrogen transformations in the Baltic proper: denitrification counteracts eutrophication. Ambio 14: $134-138$

Rumohr, J., Walger, E, Zeitzschel, B. (eds.) (1987). Seawatersediment interactions in coastal waters: An interdisciplinary approach. Lecture notes on coastal and estuarine studies 13. Springer Verlag, Berlin

Sahlsten, E., Sørensson, F. (1986). Kväveomsättande processer. In: Rosenberg, R. (ed.) Eutrofieringsläget i Kattegatt. National Swedish Environmental Protection Board, Report No. 3272, Solna, Sweden, p. 75-82

Seiki, T., Izawa, H., Date, E. (1989). Benthic nutrient remineralisation and oxygen consumption in the coastal area of Hiroshima Bay. Wat. Res. 2: 219-228

Shaffer, G. (1987). Redfield ratios, primary production, and organic carbon burial in the Baltic Sea. Deep Sea Res. 34: $769-784$

Shaffer, G., Rönner, U. (1984). Denitrification in the Baltic proper deep water. Deep Sea Res. 31 (3): 197-220

Stigebrandt, A., Wulff, F. (1987). A model for the dynamics of nutrients and oxygen in the Baltic proper. J. mar. Res. 45: $729-759$

Wassmann, P. (1984). Sedimentation and benthic mineralization of organic detritus in a Norwegian Fjord. Mar. Biol. 83: 83-94

Wulff, F., Stigebrandt, A. (1989). A time-dependent budget model for nutrients in the Baltic Sea. Global Biogeochemical Cycles 3: 63-78

Zeitzschel, B. (1980). Sediment-water interactions in nutrient dynamics. In: Tenore, K. R., Coull, B. C. (eds.) Marine benthic dynamics. Univ. S. Carolina Press, Columbia, p. $195-218$

Manuscript first received: August 7, 1989

Revised version accepted: February 23, 1990 